\title{
Thermography in the detection and follow up of chondromalacia patellae
}

\author{
M Vujčić, R Nedeljković
}

\begin{abstract}
Although diagnostic criteria for chondromalacia patellae exist, the disease is often accompanied by physical signs which are limited or non-diagnostic. Thermographic examination was performed in 157 patients with clinical diagnosis of chondromalacia patellae in $\mathbf{8 6}$ patients after surgical treatment for chondromalacia, and in 308 controls. Thermography can help the clinicians in establishing the diagnosis of chondromalacia patellae, but by itself is not sufficiently specific. The specificity of thermography was dependent on age, ranging from $90 \%$ for the 15-24 year age group to $65 \%$ for the $45-54$ year age group. Sensitivity of the method was $68 \%$. Thermography can disclose other knee disorders which imitate chondromalacia patellae.
\end{abstract}

The term infrared thermography means the recording of temperature or temperature distribution of a body by infrared radiation emited by the surface of that body. ${ }^{1-4}$ Infrared rays are an invisible part of the electromagnetic spectrum, above the visible rays and close to microwaves. $^{35-7}$ Infrared rays have physical characteristics similar to those of visible wavelengths and other waves, but differ from them in transporting large quantities of thermal energy when absorbed or emitted. ${ }^{346}$ This property is basic to understanding the principles of modern equipment imaging by the detection of infrared radiation.

Chondromalacia patellae is a common disease, whose cause is unknown, affecting the articular cartilage of the patella, and characterised by fissuring, fibrillation, and erosion, as described by many authors. ${ }^{8-20}$ Although even a minimal localised degeneration of the cartilage of the patella may produce patellofemoral pain, there are cases with extensive degeneration which are symptom free. ${ }^{16}$

Some authors use the term patellofemoral pain syndrome instead of chondromalacia and some assert that the patellofemoral pain syndrome is not synonymous with chondromalacia. ${ }^{13} 21$ Although chondromalacia patellae was recently identified as a specific entity, it is now widely thought to result from many conditions affecting the knee that lead to cartilage degeneration. ${ }^{22}$ According to some authors chondromalacia patellae may lead to osteoarthritis, but the exact relation between chondromalacia and osteoarthritis remains unclear. $^{121424}$ Clinical symptoms have been well described by several authors. ${ }^{12} \quad 16 \quad 18-20$

Diagnostic criteria proposed by Daracot and
Robinson have been widely accepted. ${ }^{16}$ Despite this the disease is often accompanied by physical signs which are limited or non-diagnostic. ${ }^{16} 24$ It is easy either to overlook or overdiagnose chondromalacia. In only 40 out of 78 knees $(51 \%)$ in which a definite clinical diagnosis of chondromalacia had been made was the diagnosis confirmed by arthroscopy. ${ }^{16}$ In the remaining $49 \%$ the articular cartilage of the patella and femoral condyles was '... smooth, glistening, with no loss of lustre and no evidence of softening.' 16

Davidson and Bass reported a thermographic pilot study in $\mathbf{4 6}$ patients with a clinical diagnosis of chondromalacia patellae (seven confirmed by arthroscopy). ${ }^{25}$ They stated that there is prepatellar cooling in comparison with the surrounding tissue in normal subjects, and differences in the thermal profile of $0.5^{\circ} \mathrm{C}$ or more over any part of the patella were considered abnormal. ${ }^{25}$ There is much disagreement among authors about the treatment required. Most recommend conservative treatment initially, for at least six months. ${ }^{8924}$ According to Bentley, about $35 \%$ of patients require operative treatment. ${ }^{26}$ Various procedures have been suggested, such as shaving, ${ }^{14} 1920$ patellectomy, ${ }^{8} 12$ 26-28 excision of the affected cartilage with or without realignment, ${ }^{14}$ transposition of the tibial tubercle, ${ }^{29}$ and many others. ${ }^{14} 21232630-32$

The aim of this study was to establish the diagnostic potential of thermography in chondromalacia patellae.

\section{Materials and methods}

This study is based partly on a review of the first 47 of 86 patients examined thermographically, who were operated on and whose cases we reported previously. ${ }^{24}$ The conclusions reached by thermography were confirmed in 32 patients $(68 \%)$ by operation. To investigate further relations between clinical signs and thermographic changes 157 patients with clinical diagnosis of chondromalacia patellae, 86 patients after surgical treatment for chondromalacia patellae, and 308 healthy subjects were reviewed. Clinical diagnoses were based on the history, physical findings according to the criteria suggested by Leslie and Bentley, ${ }^{16}$ radiography (anteroposterior, laterolateral, and axial with the knee flexed at 30,60 , and $90^{\circ}$ ), laboratory tests (erythrocyte sedimentation rate, haemoglobin concentration, minimum uric acid), and by elimination of other diseases. Thermography was carried out at a constant temperature of $18-20^{\circ} \mathrm{C}$ after a 15 minute preparation period with bare legs, as suggested for all thermographic 


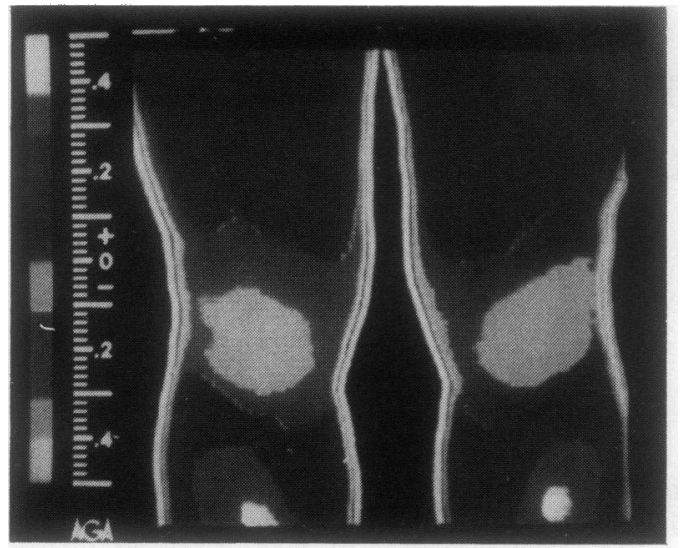

Figure 1 Thermogram of normal knees.

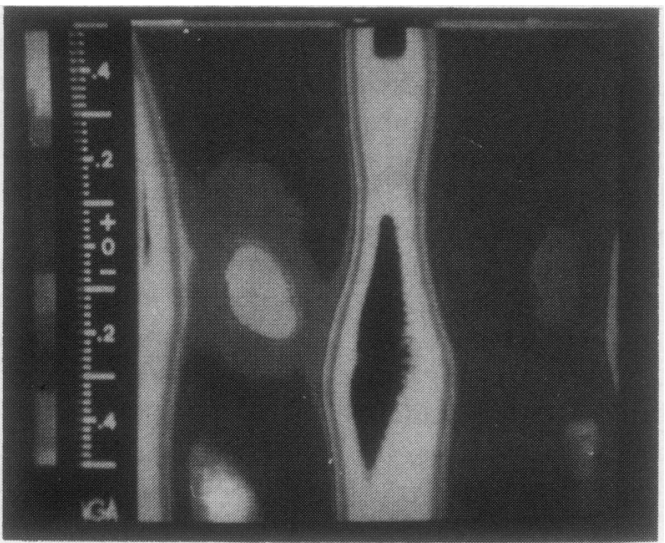

Figure 2 Early stages of chondromalacia patellae of the left knee.

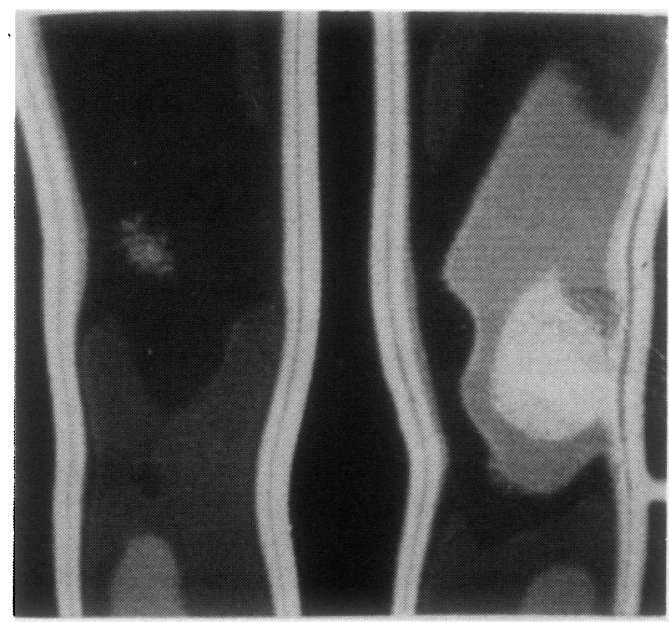

Figure 3 Advanced chondromalacia patellae of the right knee. A black and white monitor must be used to distinguish between the vascular net around the patella and an inflammation.

examinations. ${ }^{1} 2433-36$ AGA 780 medical equipment was used.

The thermographic findings were considered normal when $(a)$ there was thermal symmetry over the knees; $(b)$ the knees were colder than the adjacent areas; $(c)$ a narrow temperature isotherm produced a well shaped oval central prepatellar zone (fig 1) or, in adipose subjects a well shaped line tending from the superolateral towards the inferomedial part of the knee. As shown in fig 1 there is an obvious gradient between the prepatellar zone, the coldest area, and the fossa poplitea, the warmest part of the knee.
Chondromalacia patellae of the knee was present when (a) there was asymmetry; $(b)$ narrowing, irregular form or diminishing of the prepatellar zone of more than $50 \%$; $(c)$ isotherms spreading from the adjacent areas (except that of varicose veins) over the prepatellar zone. Figures 2 and 3 show the early and advanced stages of chondromalacia patellae.

\section{Results}

Table 1 shows the age distribution of patients with the clinical diagnosis of chondromalacia patellae. Women predominated in a ratio of $1 \cdot 5: 1$ or $1 \cdot 65: 1$ if the number of affected knees are compared.

As shown in table 2, among the female patients a clinical diagnosis of chondromalacia was established for 18 on the left knee, 23 on the right knee, and 54 on both knees. Of the 18 women with clinically established left sided chondromalacia, thermography showed another disease (collateral ligament lesion, quadriceps enthesopathy, ischialgia) in four (22\%). In six of the 18 women thermograms were normal, in four cases clinical diagnosis was confirmed, and in three cases thermographic changes were seen in both knees. Of 23 women with clinically established diagnoses of right knee chondromalacia patellae, three had thermographic findings of another disease (meniscal lesions, collateral ligament lesions, gonarthrosis decompensata), three had changes in both knees, and 16 patients $(70 \%)$ had thermographic changes over the right knee. Two (4\%) of 54 women with clinical chondromalacia patellae in both knees had normal thermograms, three had changes of another disease, and 44 had thermographic changes in both knees. Owing to t.' : presence of varicose veins over the knee thermographic results could not be interpreted in two women with a clinical diagnosis of chondromalacia in one knee and in five women and two men with a clinical diagnosis of chondromalacia in both knees. The results obtained with male patients were similar (table 2). In general, thermograms were normal in eight female $(8 \%)$ and 12 male patients (19\%), non-interpretable in seven women $(7 \%)$ and two men $(3 \%)$, and with changes suggesting chondromalacia in 70 female (74\%) and 41 male patients (66\%). Thermography indicated some other diseases in 16 patients (10\%), mainly lateral collateral ligament lesions.

Fourteen of 25 randomly selected patients (56\%) who underwent an operation had symptoms similar to those before surgery (table 3). In all but one patient the thermograms were abnormal (93\%). We also found abnormal thermograms in three asymptomatic patients (one woman, two men) (27\%). Figure 4 shows a normal thermogram of the right knee six months after operation, but with quadriceps thinning.

When 308 healthy subjects were examined some subjects (of all ages) had thermograms which were identical with those of patients with chondromalacia patellae, the prevalence increasing with age. Sixty three of $308(20 \%)$ healthy controls had thermographic findings identical to 
Table 1 Age and sex distribution of patients with clinical diagnosis of chondromalacia patellae

\begin{tabular}{|c|c|c|c|c|c|c|c|}
\hline \multirow{2}{*}{$\begin{array}{l}\text { Age } \\
\text { (years) }\end{array}$} & \multicolumn{3}{|c|}{ Women } & \multicolumn{3}{|l|}{ Men } & \multirow[t]{2}{*}{ Total } \\
\hline & $\begin{array}{l}\text { Left } \\
\text { knee }\end{array}$ & $\begin{array}{l}\text { Right } \\
\text { knee }\end{array}$ & $\begin{array}{l}\text { Both } \\
\text { knees }\end{array}$ & $\begin{array}{l}\text { Left } \\
\text { knee }\end{array}$ & $\begin{array}{l}\text { Right } \\
\text { knee }\end{array}$ & $\begin{array}{l}\text { Both } \\
\text { knees }\end{array}$ & \\
\hline $\begin{array}{l}15-19 \\
20-24 \\
25-29 \\
30-34 \\
35-39 \\
40-44 \\
45-49 \\
50-54 \\
55-59\end{array}$ & $\begin{array}{l}1 \\
3 \\
4 \\
4 \\
1 \\
2 \\
1 \\
2\end{array}$ & $\begin{array}{l}-2 \\
2 \\
7 \\
5 \\
3 \\
1 \\
2 \\
1\end{array}$ & $\begin{array}{r}3 \\
4 \\
7 \\
7 \\
7 \\
6 \\
12 \\
5 \\
3\end{array}$ & $\begin{array}{r}6 \\
2 \\
7 \\
2 \\
2 \\
-\end{array}$ & $\begin{array}{l}\overline{1} \\
3 \\
4 \\
3 \\
2 \\
1 \\
1\end{array}$ & $\begin{array}{l}1 \\
4 \\
7 \\
7 \\
1 \\
5 \\
2 \\
1\end{array}$ & $\begin{array}{r}11 \\
13 \\
15 \\
36 \\
28 \\
11 \\
24 \\
11 \\
8\end{array}$ \\
\hline Total & 18 & 23 & 54 & 19 & 15 & 28 & 157 \\
\hline
\end{tabular}

Table 2 Thermographic findings in patients with clinical diagnosis of chondromalacia patellae

\begin{tabular}{|c|c|c|c|c|c|c|c|}
\hline \multirow{3}{*}{$\begin{array}{l}\text { Thermographic } \\
\text { changes }\end{array}$} & \multicolumn{6}{|c|}{ Clinical diagnosis } & \multirow[t]{3}{*}{ Total } \\
\hline & \multicolumn{2}{|c|}{ Left knee } & \multicolumn{2}{|c|}{ Right knee } & \multicolumn{2}{|c|}{ Both knees } & \\
\hline & Women & Men & Women & Men & Women & Men & \\
\hline \multirow{6}{*}{$\begin{array}{l}\text { Left knee } \\
\text { Right knee } \\
\text { Both knees } \\
\text { No changes } \\
\text { Another disease } \\
\text { Results } \\
\text { uninterpretable }\end{array}$} & 4 & 10 & - & - & - & 3 & 17 \\
\hline & - & 1 & 16 & 7 & - & - & 24 \\
\hline & 3 & 4 & 3 & - & 44 & 16 & 70 \\
\hline & 6 & 2 & - & 4 & 2 & 7 & 21 \\
\hline & 4 & 2 & 3 & 4 & 3 & - & 16 \\
\hline & 1 & - & 1 & - & 5 & 2 & 9 \\
\hline Total & 18 & 19 & 23 & 15 & 54 & 28 & 157 \\
\hline
\end{tabular}

Table 3 Thermographic findings in 25 patients one to five years after an operation for chondromalacia patellae

\begin{tabular}{|c|c|c|c|c|c|}
\hline \multirow[t]{2}{*}{ Thermogram } & \multicolumn{2}{|l|}{ Women } & \multicolumn{2}{|l|}{ Men } & \multirow[t]{2}{*}{ Total } \\
\hline & $\begin{array}{l}\text { No } \\
\text { symptoms }\end{array}$ & $\begin{array}{l}\text { With } \\
\text { symptoms }\end{array}$ & $\begin{array}{l}\text { No } \\
\text { symptoms }\end{array}$ & $\begin{array}{l}\text { With } \\
\text { symptoms }\end{array}$ & \\
\hline $\begin{array}{l}\text { Normal } \\
\text { Changed }\end{array}$ & $\begin{array}{l}5 \\
1\end{array}$ & $\begin{array}{l}1 \\
8\end{array}$ & $\begin{array}{l}3 \\
2\end{array}$ & $\begin{array}{l}0 \\
5\end{array}$ & $\begin{array}{r}9 \\
16\end{array}$ \\
\hline Total & 6 & 9 & 5 & 5 & 25 \\
\hline
\end{tabular}

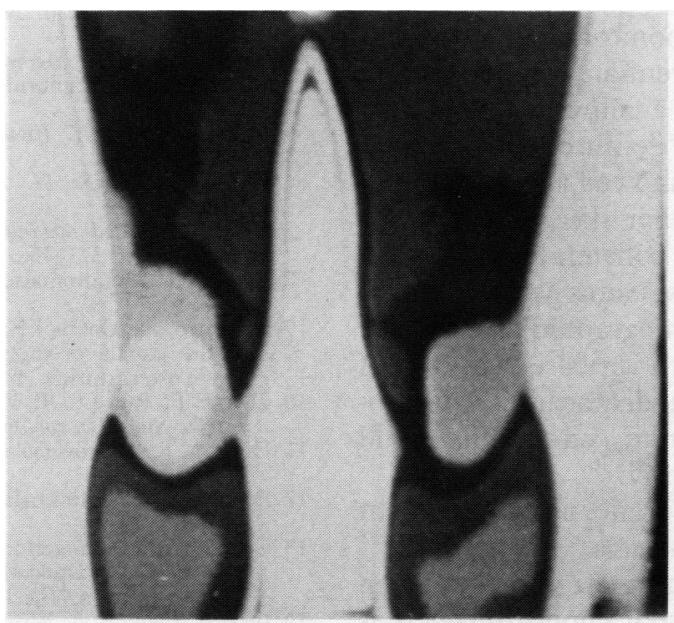

Figure 4 Normal thermogram of the right knee six months after operation. Note wasting of the quadriceps.

those with chondromalacia patellae (false positive) but the prevalence varied with age, being $10 \%(7 / 68)$ for $15-24$ year olds, $16 \%(12 / 76)$ at age $25-34,19 \%(16 / 83)$ at age $35-44$, and increasing to $35 \%(28 / 81)$ in those aged between 45 and 54.

\section{Discussion}

Diagnosis and treatment of chondromalacia patellae is controversial. Although there are widely accepted criteria for diagnostic purposes, these are challenged by a report which criticises the criteria, both clinical and subjective, and stresses that an accurate diagnosis can be made only with arthroscopy. ${ }^{16}$ Since Leslie and Bentley in 1978 showed unsatisfactory results using clinical criteria it is now widely agreed that accurate diagnosis of chondromalacia patellae is difficult. Additional methods are needed to establish the diagnosis. Arthroscopy is a valuable method for the diagnosis of chondromalacia patellae. ${ }^{16}$ 37-40 Although it provides an easy method for examining the patellofemoral joint, there are some problems. Chondromalacia patellae is a common disease, but arthroscopy has not been used widely enough. Furthermore, many patients are reluctant to accept arthroscopic investigation. Thus it has been necessary to establish the diagnosis using the following criteria: $(a)$ presence of long term 'typical symptoms; $(b)$ presence of objective clinical signs as suggested by Leslie and Bentley ${ }^{16}$; and (c) elimination of other diseases.

We noticed that the distribution of isotherms over the knees of healthy subjects are characterised by the signs detailed in 'Materials and methods'. Many diseases alter some or all of these signs. The thermogram of a knee affected by arthritis, for instance, shows some apparent changes affecting all of it, and an inflamed knee can usually be distinguished from normal at first sight. Thermography provides information on the side, the area affected, and the intensity of the inflammation, quickly, objectively, and with accuracy. ${ }^{10} 11 \quad 41-44$

In patients with unilateral chondromalacia patellae we have also seen various degrees of asymmetry due to the narrowing, diminishing, and disappearance of the cold prepatellar zone. Later, as Davidson and Bass noted, a prepatellar vascular net appeared (fig 2). The same changes were noted in patients with arthrosis, but with an irregular isotherm pattern. These observations refer to 'typical' unilateral changes. There are, however, many patients in whom it is not easy to distinguish these two diseases. It is not possible to differentiate chondromalacia from sequelae of rheumatoid arthritis in the case of 'burnt out' disease in the knee.

In the presence of synovial irritation (which is rare and is detected mostly in advanced cases) the thermogram shows the appearance of high temperature isotherms, which could not always be distinguished from those in arthritis or osteoarthritis. Thus other tests are required for diagnosis.

Forty seven of 86 patients, whose cases we reported previously, ${ }^{24}$ underwent an operation, and in 32 the thermographic conclusions were confirmed $(68 \%$, indicating the specificity of thermography. The main discrepancies were in the thermographic findings in adipose female patients, which were unclear, being described as osteoarthritis or normal. Table 4 shows that some healthy subjects of all ages have the same thermographic findings as those seen in patients with chondromalacia (false positives). The prevalence of false positive results increases with age and the specificity of thermography is satisfactory only up to the age of 25 , where the 
Table 4 Thermography of the knees of healthy men and women

\begin{tabular}{|c|c|c|c|c|c|c|}
\hline \multirow[t]{2}{*}{ Age (years) } & \multicolumn{3}{|l|}{ Men } & \multicolumn{3}{|l|}{ Women } \\
\hline & $\begin{array}{l}\text { Normal } \\
\text { No }(\%)\end{array}$ & $\begin{array}{l}\text { Chondromalacia } \\
\text { No }(\%)\end{array}$ & $\begin{array}{l}\text { Total } \\
\text { No }\end{array}$ & $\begin{array}{l}\text { Normal } \\
\text { No }(\%)\end{array}$ & $\begin{array}{l}\text { Chondromalacia } \\
\text { No }(\%)\end{array}$ & $\begin{array}{l}\text { Total } \\
\text { No }\end{array}$ \\
\hline $\begin{array}{l}15-19 \\
20-24 \\
25-29 \\
30-34 \\
35-39 \\
40-44 \\
45-49 \\
50-54\end{array}$ & $\begin{array}{l}15(94) \\
15(88) \\
20(91) \\
16(84) \\
20(83) \\
12(80) \\
15(75) \\
14(70)\end{array}$ & $\begin{array}{ll}1 & (6) \\
2 & (12) \\
2 & (9) \\
3 & (16) \\
4 & (17) \\
3 & (20) \\
5 & (25) \\
6 & (30)\end{array}$ & $\begin{array}{l}16 \\
17 \\
22 \\
19 \\
24 \\
15 \\
20 \\
20\end{array}$ & $\begin{array}{l}14(93) \\
17(85) \\
15(83) \\
13(76) \\
20(80) \\
15(79) \\
14(67) \\
10(50)\end{array}$ & $\begin{aligned} & 1(7) \\
& 3(15) \\
& 3(17) \\
& 4(24) \\
& 5(20) \\
& 4(21) \\
& 7(33) \\
& 10(50)\end{aligned}$ & $\begin{array}{l}15 \\
20 \\
18 \\
17 \\
25 \\
19 \\
21 \\
20\end{array}$ \\
\hline Total & $127(83)$ & $26(17)$ & 153 & $118(76)$ & $37(24)$ & 155 \\
\hline
\end{tabular}

reliability of results is $90 \%$. In older subjects the specificity falls so that after the age of 45 thermographic results are unreliable.

What is the reason for so many thermographic changes in healthy subjects? We suggest that it may be some kind of 'silent' arthrosis. Morsher ${ }^{23}$ and other authors ${ }^{21} 37$ reported that chondromalacia patellae may be found by arthrotomy in a number of asymptomatic patients. A 'silent' arthrosis might be also be present in patients with thermographic changes in both knees but with symptoms in only one. This was confirmed in a number of patients who after an operation on one knee developed retropatellar pain in the opposite knee, requiring a further operation. Goodfellow and coauthors state that chondromalacia is usually bilateral. ${ }^{13}$ Why, therefore, is it possible to find symptomatic chondromalacia without thermographic changes over the knees? Additionally, why do some symptomatic subjects with a clinically 'definite' diagnosis of chondromalacia have no changes at arthroscopy or arthrotomy. ${ }^{2}$ The answers to these questions would only be speculation. With our thermographic system monochrome thermography using a black and white monitor should be used. It is not possible to differentiate clearly varicose veins from arthritis with a colour monitor.

Some patients with a 'definite' clinical diagnosis of chondromalacia showed typical thermographic findings of another disease, usually a faint lesion of the lateral collateral ligament.

We found that varicose veins were the only obstacle to reliable thermographic assessment. Thus in nine patients with varicose veins out of 157 patients with a clinical diagnosis of chondromalacia patellae no definite conclusions could be reached by thermography.

There are many different opinions about the causes of chondromalacia. 8141921232628 31 45-47 The most interesting are the data given by Wiberg, who shows that chondromalacia is apparently present in nearly all subjects over 30 years of age. ${ }^{47}$ If this statement is true an arthroscopic interpretation of the causes of knee pain must be treated with caution. Even in such specific diagnostic examinations chondromalacia might only be secondary and the pain might have been caused by some other disease. Owing to the limitations of arthroscopy ${ }^{39} 48$ one can logically conclude that some misdiagnoses may be made with that method. Unlike Wiberg, Casscells found normal articular patellar surfaces by necropsy in $34 \%$ of subjects over the age of $50 .{ }^{49}$ According to Morsher, whenever there is pain in the knee, but no clinical diagnosis is made, it is caused by chondromalacia in $90 \%$ of the cases. ${ }^{23}$

\section{Conclusions}

1 Thermography can help the clinician in establishing the diagnosis of chondromalacia patellae, but this method by itself is not sufficiently specific.

2 In a series of 47 surgically treated patients with chondromalacia, thermographic conclusions were confirmed in $32(68 \%)$.

3 The specificity of thermography was dependent on age. Sixty three $(20 \%)$ of 308 healthy subjects showed thermographic changes identical to those of subjects with chondromalacia patellae, but this percentage varied according to age so that for 15-24 year olds the specificity was $90 \%, 84 \%$ for the age group $25-34,81 \%$ for the age group $35-44$ years, and only $65 \%$ for the group aged $45-54$ years.

4 The results of thermographic examinations are best in young patients with one knee affected, worst in obese women with two knees affected, and of no value in patients with varicose veins over the knee.

5 Thermography can improve the clinician's objective judgment of some postoperative symptoms.

6 Thermography can disclose other knee disorders which are not clinically evident and which imitate chondromalacia patellae.

1 Cohen G J, Haberman-Buesche D J A, Brueschke E E. Medical thermography: a summary of current status. Radio Clin North Am 1965; 3: 403-31.

2 European Thermographic Association. Thermographic terminology. Acta Thermographica 1978; (suppl): 1-30.

3 Houdas Y, Ring E F J. Human body temperature its measurement and regulation. New York-London: Plenum Press, 1982

4 Woodrough R E. Medical infra-red thermography principles and practice. Cambridge: Cambridge University Press, 1982

5 Djuric B, Čulum Ž. Fizika IV deo-optika. Beograd: Naučna Knjiga, 1978.

6 Kulušić P. Fizika II. Zagreb: Elektrotehnički Fakultet, 1986.

7 Licul F. Elektrodijagnostika i elektroterapija. Zagreb: Školska Knjiga, 1981: $371-436$.

8 Bentley G. Chondromalacia patellae. $\mathcal{F}$ Bone foint Surg [Am] 1970; 52: 221-32.

9 Björkström S, Goldie I F. Hardness of the subchondral bone of the patella in the normal state, in chondromalacia, and in osteoarthritis. Acta Orthop Scand 1982; 53: 451-62.

10 Cave E F, Rowe C R, Yee L B K. Chondromalacia of the patella. Surg Gynecol Obstet 1945; 81: 446-50

11 Devas M B. Chondromalacia of the patella. Clin Orthop 1960 18: $54-61$

12 Evans C D. Chondromalacia patellae. Proc $R$ Soc Med 1968; 59: 626-7.

13 Goodfellow J, Hungerford D S, Woods C. Patello-femoral joint mechanics and pathology. 2. Chondromalacia patellae. f Bone foint Surg [Br] 1976; 58: 291-9.

14 Insall J, Falvo K A, Wise D W. Chondromalacia patellae. A prospective study. F Bone Joint Surg [Am] 1976; 58: 1-8.

15 Johnson R P, Brewer J B. Mechanical disorders of the knee. In: McCarty J D, Arthritis and allied conditions. 10th ed. Ph: McCarty J D, Arthritis and allied conditions.

16 Leslie J J, Bentley G. Arthroscopy in the diagnosis of chondromalacia patellae. Ann Rheum Dis 1978; 37:540-7.

7 Outerbridge R E. The etiology of chondromalacia patellae. J Bone foint Surg [Br] 1961; 43: 752-7.

18 Robinson A R, Daracott J. Chondromalacia patellae. Ann Phys Med 1970; 10: 286-90.

19 Wiles P, Andrews P S, Bremner R A. Chondromalacia of the patella. A study of later results of excision of articular cartilage. F Bone foint Surg [Br] 1960; 42: 65-70.

20 Wiles P, Andrews P S, Devas M B. Chondromalacia of the patella. F Bone foint Surg [Br] 1956; 38: 95-113.

21 Chaklin V D. Injuries to the cartilages of the patella and femoral condyle. F Bone foint Surg 1939; 21 : 133-40.

22 Insall J. Current concepts review: patellar pain. $\mathcal{F}$ Bone foint Surg $[A m]$ 1982; 64: 147-52.

23 Morsher E. Osteotomy of the patella in chondromalacia. Arch Orthop Trauma Surg 1978; 92: 139-47. 
24 Nedeljković $\mathbf{R}$, Vujčić $\boldsymbol{M}$. Vrijednost termografije u dijagnostici hondromalacije patele. Medicinski Vjeskik 1986; 2: $57-61$.

25 Davidson J W, Bass A L. Thermography and patelo-femoral pain. Acta Thermographica 1979; 4: 98-103.

26 Bentley $G$. The surgical treatment of chondromalacia patellae. Ұ Bone foint Surg $[\mathrm{Br}] 1978 ; 60: 74-81$.

F Bone foint Surg [Br] 1978; 60: 74-81.
27 Fellander M. The results of chondrectomy in chondromalacia of the patella. Acta Orthop Scand 1951;21: 300-18.

28 Haliburton R A, Sullivan R C. The patella in degenerative joint disease. Arch Surg 1958; 77: 677-83.

29 Devas M, Golski A. Treatment of chondromalacia patellae by transposition of the tibial tubercle. $B M \mathcal{F} 1973 ; \mathrm{i}$ : 589-91.

30 Maquet P G J. Biomechanics of the knee: with application to the pathogenesis and surgical treatment of osteoarthritis. Berlin: Springer, 1976.

31 Pećina $M$. Longitudinalna osteotomija patele. U. In: Pećina M, ed. Koljeno, primjenjena biomehanika. Zagreb: Pecina M, ed. Koljeno, primjenjena biomehanika.
Jugoslavenska Medicinska Naklada, 1982: 159-69.

32 Pridie K H. A method of resurfacing osteo-arthritic knee joints. F Bone foint Surg [Br] 1959; 41 : 618.

33 Collins A I, Ring E F J, Cosh J A, Bacon P A. Quantitation of thermography in arthritis using multi-isothermal analysis. Ann Rheum Dis 1974; 33: 113-5.

34 Collins A J, Cosh J A. Temperature and biochemical studies of joint inflammation. Ann Rheum Dis 1970; 29: 386-91.

35 Cosh J A, Ring E F J. Thermography and rheumatology. Rheumatol Phys Med 1970; 7: 342-8.

36 Ring E F J. Objective measurement of arthritis by thermography. Acta Thermographica 1980; 5: 96-7.

37 Casscells $S W$. The place of arthroscopy in the diagnosis and treatment of internal dengement of the knee and analysis of 1000 cases. Clin Orthop 1980; 151: 135-42.
38 Curran W P, Woodward E P. Arthroscopy: its role in diagnosis and treatment of athletic knee injuries. Am $\mathrm{J}$ Sports Med $1980 ; 8: 415-8$.

39 Gallannaugh S. Arthroscopy of the knee joint. BMF 1973; 3: 285-6.

40 Joyce M J, Mankin H J. Caveat arthroscopos: extra-articular lesions of bone simulating intra-articular pathology of the knee. F Bone foint Surg [Am] 1983; 65: 289-92.

41 Vuičić M Dürrigl Th Thermografija u reumatolegiji: fugosl. Akad. Znanosti i Umjetnosti 1987. Osijek: Radovi Zavoda za znanstv. rad, 1987

42 Vujčić $M$, Janković B, Vujčić $D$, Šram $K$, Adam V. Termografija koljena u bolesnika s reumatoidnim artritisom (korelacija sa zdravim osobama), reumatoidni artritis. Niška Banja 1984: 417-20.

43 Vujčić M. Ocjena efekta erazona u bolesnika s reumatoidnim artritisom kvantitativnom termografijom, supplement. Krka u medicini i farmaciji Novo Mesto: Krka, tovarna zdravil, 1985 .

44 Ring E F J. Quantitative thermography in arthritis using the AGA integrator. Acta Thermographica 1977; 2: 172-6.

45 Chrisman $\mathrm{D}$. Biomechanical aspects of degenerative joint disease. Clin Orthop 1969; 64: 77-86.

46 Peco M, Pećina M. Patela alta i patela infera. U. In: Pećina M, ed. Koljeno, primjenjena biomehanika. Zagreb: Jugoslavenska medicinska Naklada 1982: 119-33.

47 Wiberg G. Roentgenographic and anatomic studies on the femoropatellar joint with special reference to chondromalacia patellae. Acta Orthop Scand 1941; 12: 319-410.

48 Jackson W R, Abe $I$. The role of arthroscopy in the management of disorders of the knee. $\mathcal{F}$ Bone foint Surg [Br] 1972; 54: 310-22.

49 Casscells S W. Chondromalacia of the patella. $\mathcal{F}$ Pediatr Orthop 1982; 2: 560-4. 